\title{
Taking the incidence of false child sexual abuse allegations more seriously
}

Emma Charlene Lubaale

LLB LLM LLD

Post-doctoral researcher Institute of International and Comparative Law in Africa, South African Research Chairs Initiative (SARChI), Department of Public

Law, University of Pretoria

\section{OPSOMMING}

Vals bewerings van seksuele mishandeling van kinders-die behoefte tot ' $n$ meer indringende ondersoek

Kindermishandeling is ' $n$ ernstige misdryf wat die daadwerklike vervolging van die oortreders noodsaak. In gevalle waar die oortreder 'n kennis is, word laasgenoemde noodsaaklikheid selfs sterker genoodsaak vanweë die feit dat daar 'n vertouensbreuk plaasvind. Sodanige vervolgings moet egter nie tot so vlak gedryf word dat dit onregmetige vervolgings tot gevolg het nie. Gevalle van onregmatige vervolgings, hoewel skaars, ondermyn die vertoue in behoorlike regspleging. Die onderhawige artikel onderskraag die behoefte om valse bewerings van kindermishandeling en gevalle van onregmatige vervolgings met meer erns te bejeën. Gevolglik word die noodsaaklikheid om meer gewig aan deskundige getuienis te heg onderskryf asook die behoefte aan betekenisvolle kruisondervraging. Die artikel lig verder toe dat indien gevalle van onregmatige vervolgings met meer erns bejeën word dit by implikasie sal vereis dat die deure van onskuld nie gesluit word sou addisionele getuienis voorsien word wat verdere bewerings van onskuld ondersteun nie.

\section{Introduction}

When children's allegations of abuse were discounted out of hand, they were victimised not only by their abusers but by a society that neither believed nor protected them. Conversely, when allegations that have no basis in fact are believed, innocent adults can face a lifetime of imprisonment, shame, ostracism, and devastation. ${ }^{1}$

This quotation outlines the current dilemma with regard to the prosecution of child sexual abuse (CSA) cases. Prior to 1980, CSA was a secretive and private issue ${ }^{2}$ and allegations of CSA were received with

1 Shanks 'Cross-Examination of a child witness' 2009-2010 Legal Research Paper Series 32.

2 Finkelhor 'Current information on the scope and nature of child sexual abuse' 1994 The future of children 31; Finkelhor 'The international epidemiology of child sexual abuse' 1994 Child Abuse Research \& Neglect 409; Younts 'Evaluating and admitting expert opinion testimony in child sexual abuse prosecutions' 1995 Duke Law Journal 693-694.

How to cite: Lubaale 'Taking the incidence of false child sexual abuse allegations more seriously' 
disbelief. $^{3}$ Disbelief in CSA was compounded by myths: that children lie about being sexually abused; they fantasise about being sexually abused; all child sexual abuse cases have to be supported by medical evidence; children are abused by strangers; they report CSA immediately; and they scream during the abuse. ${ }^{4}$ These myths have consistently been challenged as lacking empirical backing and, consequently, there is an ongoing shift in how society and the justice system view CSA allegations. Presently, CSA receives significantly heightened social and legal awareness. This awareness has brought with it a zealous attempt by criminal justice systems (CJSs) to hold offenders to account. This shift in attitude is a welcome development, but sometimes gives rise to a dogmatic belief in all CSA allegations - with limited effort on the part of concerned professionals to meaningfully substantiate these allegations. The increasing incidence of false CSA allegations and wrongful convictions arguably indicates that the pendulum has swung too far: such allegations of CSA are accepted as true without any real or meaningful investigation.

Presently, CSA presents the prosecution with innumerable challenges in proving that CSA occurred; equally the accused in CSA cases are confronted with the challenge to prove that the allegations against them are false. The myth that children lie about being sexually abused must be laid to rest. Equally, overzealous attempts to hold child sexual offenders to account must not cause CJSs to rule out the possibility of false CSA allegations. Otherwise a new myth would be created: that children never lie or are never mistaken about being sexually abused. Therefore, there is an urgent need to strike a proper balance between discarding the myths about CSA and ensuring that the swing of the pendulum does not lead to wrongful convictions. This article underscores the role of mental health professionals (MHPs) and meaningful cross-examination in striking this balance. Equally, it underscores the need for an appropriate forum in which new evidence is discovered with the effect of proving the innocence of wrongly convicted persons.

\section{The Meaning and Extent of False Child Sexual Abuse Allegations}

False allegations of CSA are different from 'unfounded' or 'unsubstantiated' CSA allegations. Many cases of alleged sexual abuse are labeled by investigators as 'unfounded' or 'unsubstantiated': Yuille et al note up to half of reported cases. Yuille et al's findings seem defensible as very young children may lack verbal or other communication skills

3 Ibid.

$4 \quad$ Muller \& Holley Introducing the child witness (2009) 148-154.

5 Yuille et al 'The nature of allegations of child sexual abuse' in Ney (ed) True and false allegations of child sexual abuse: assessment and case management (1995) 22; see Green 'True and false allegations of sexual abuse in child custody disputes' $1986 \mathrm{~J}$. Am. Acad. Child Psychiatry 449-456. 
and may be unable to provide sufficient detail to determine whether abuse has occurred. Moreover, a child with communication difficulties by reason of an inability to see, speak or hear, may be unable to give an account of their abuse. Similarly, poor investigative techniques may prevent a child from telling what happened. Thus, many cases labeled unsubstantiated or unfounded may be genuine. On the other hand, Yuille et al describe a false allegation to constitute one or more of the following characteristics: ${ }^{6}$

- An allegation that is wholly untrue; that is, one in which none of the alleged events occurred,

- An allegation in which an innocent person has been accused but the allegation is otherwise valid. This is a case of 'perpetrator substitution' in which an abused child discloses his or her abuse but accuses someone other than the actual perpetrator,

- An allegation that contains a mixture of true and false features; that is, the child describes some events that actually occurred and adds others that did not occur.

Research documents that although CSA is on the rise, so also are false CSA allegations. ${ }^{7}$ Increasingly, it is clear that although many victims are honest, some are mistaken. It does not necessarily follow that when a child victim appears honest and trustworthy, that their allegations are true. Brongersma explains that with the heightened awareness of CSA and the wide definition of sexual abuse, some children may interpret the accused's affection for sexual abuse. ${ }^{8}$ Clarke-Stewart et $a l^{9}$ add that repeated questioning and suggestive interviews by law enforcement authorities can cause children to interpret otherwise non-abusive

$6 \quad$ Yuille et al supra $\mathrm{n} 5$ at 23-24.

7 For a demonstration of the reality of false allegations, see Schuman 'False accusations of physical and sexual abuse' 1986 Bull. Am. Acad Psychiatry Law 5-21; Coleman, \& Clancy 'False allegations of child sexual abuse: Why is it happening? What can we do?' 1990 Criminal Justice 14-47; Benedeck \& Schetky 'Allegations of sexual abuse in child custody and visitation disputes' in Benedek \& Schetky (eds) Emerging issues in child psychiatry and the law (1985) 145-156; Blush \& Ross 'Investigation and case management issues and strategies' 1990 Issues in child abuse accusations 152-160; Gordon 'False allegations of abuse in child custody disputes' 1985 Minnesota Family Law Journal 225-228; Kase-Boyd 'Fictitious allegations of sexual abuse in marital dissolutions' 1988 Family Law News 50-52; Sheridan 'The false child molestation outbreak of the 1980s: An explanation of the cases arising in the divorce context' 1990 Issues in Child Abuse Accusations 146-151; Yates \& Musty 'Preschool children's erroneous allegations of sexual molestation' 1988 American Journal of Psychiatry 989992; Faller 'Possible explanations for child sexual abuse allegations in divorce' 1991 American Journal of Orthopsychiatry 86-91.

8 Brongersma "The meaning of "indecency" with respect to moral offences involving children' 1980 British Journal of Criminology 30.

9 Clarke-Stewart et al 'Manipulating children's interpretations through interrogation' 1989 Paper presented at SRCD; Wakefield \& Underwager 'Manipulating the child abuse system' 1989 Issues in Child Abuse Accusations 58-67; White \& Quinn 'Investigatory independence in child sexual abuse evaluation: Conceptual considerations' 1988 The Bulletin of the American Academy of Psychiatry and the Law 269-278. 
conduct as sexual abuse. Some CSA allegations may be on account of a mistake but certain commentators ${ }^{10}$ submit that some false CSA allegations are intentional. Research ${ }^{11}$ documents that parental conflicts during custody, divorce and separation proceedings may also result in the use of CSA allegations. Genuine CSA allegations cannot be ruled out during custody and divorce proceedings in view of the fact that the family may no longer be trying to keep together and, to hide this particular secret. However, there are studies which demonstrate that, in some situations, the allegations are false. Klein ${ }^{12}$ argues that although some CSA allegations during these proceedings are false, it is critical to guard against a tendency to view all CSA allegations during these proceedings as false.

There is a lack of authoritative empirical studies illustrative of the prevalence of false allegations. But to take an extreme view that false allegations never happen is incorrect. Available studies of false allegations of CSA show that although these allegations are rare, they still exist. ${ }^{13}$ Thus, although CSA is a horrible crime that justifies CJSs' efforts to aggressively hold offenders accountable, it is equally critical to ensure that the innocent are not punished for crimes they did not commit.

Discussions on false CSA allegations are often advanced in the abstract: to inform the debate going forward, it is critical to engage with selected cases. The discussion in the next section engages this with reference to two cases.

10 Derdeyn 'Child psychiatry and the law: The family in divorce, issues of parental anger' 1983 Journal of the American Academy of Child Psychiatry 385-391. See also Green 1986 J. Am. Acad. Child Psychiatry supra n 5 at 449 456; Everson \& Boat 'False allegations of sexual abuse by children and adolescents' 1989 Journal of American Academy of Child \& Adolescent Psychiatry 230-235; Ekman 'Kids' testimony in court: The sexual abuse crisis' in Ekman (ed) Why kids lie (1989) 152-180; Emery 'Interparental conflict and the children of discord and divorce' 1982 Psychological Bulletin 310-330; La Rooy et al 'Repeated interviewing: A critical evaluation of the risks and potential benefits' in Kuhnle \& Connell (eds) The evaluation of child sexual abuse allegations: A comprehensive guide to assessment and testimony) (2009) 327-335.

11 Fisk 'Abuse: The new weapon' 1989 The National Law Journal 20-25; Derdeyn 1983 Journal of the American Academy of Child Psychiatry supra $n$ 10 at 385-391; Hall 'Child abuse as a tool' 1989 Register Report 12-13; Green 1986 J. Am. Acad. Child Psychiatry supra n 5 at 449-456.

12 Klein 'Forensic issues in sexual abuse allegations in custody/visitation litigation' 1994 Law and Psychology Review 347.

13 See e.g. studies by Klein idem 347; Jones \& McGraw 'Reliable and fictitious accounts of sexual abuse to children' 1987 Journal of Interpersonal Violence 27. 


\section{The Reality of False CSA Allegations and Wrongful Convictions in Selected Cases}

\section{State of North Carolina v Sylvester Smith ${ }^{14}$}

This 1984 case involves two girls, four and six years of age, who were sexually molested by their nine year old cousin at their family home in Bellville, North Carolina. When the molestation was discovered the girls' grandmother pressured them to accuse Sylvester Smith, the boyfriend of one of their mothers, of committing the sexual abuse instead of their cousin. The girls accused Smith and, based on their testimony, he was convicted of rape by the jury and sentenced to two consecutive life sentences. Twenty years later, in 2004, the victims came forward and recanted, confessing that Smith had never molested them and that they were pressured into lying by their grandmother, Mrs Fannie Mae Davis, who was trying to protect their cousin (her grandson). In November 2004, Smith's conviction was overturned. ${ }^{15}$

In 1984 , at trial, the court held that the state had proved the case against Smith beyond reasonable doubt. The prosecution advanced evidence through a number of witnesses. The State's evidence tended to show that one night during the weekend of 2 March, 1984, the accused, Smith, entered the bedroom of the complainants, Gloria Ogundeji and Janell Smith, age four and five respectively, and engaged in sexual intercourse with both girls. At trial, Gloria testified that the accused came into the bedroom where she and Janell were sleeping, slipped off his pants and touched her in her 'project' with his 'worm'. Janell testified that the accused threatened to beat her 'half to death', pushed her down on the bed, and stuck his 'thing in [her] project'. She also testified that he '[stuck] his hand in [her] butt'. At trial the complainants were asked to show the jury where their 'project' was and both independently pointed to their vaginal areas. Gloria indicated the same area when asked to show where the 'worm' is and also identified both the 'project' and the 'worm' on anatomically correct dolls used as exhibits at trial. Janell pointed to her anal area when asked to show where her 'butt' was.

Mrs Fannie Mae Davis, the girls' grandmother, testified that she went to the mobile home where Smith, Ann, Gloria and Janell were living on 3 March 1984 and that Gloria had led her into the bedroom to tell her what Smith had done to her. She testified that Gloria told her that Smith had '[gone] in her'. She also testified that Gloria indicated to her that Smith had put his 'peeter' in her 'project' and in her 'butt' using his finger. She

14 State of North Carolina v Sylvester Smith 337 S.E 2 d 833 (1985) 315 N.C.76.

15 For further discussion on the circumstances surrounding the false child sexual abuse allegations and ultimate exoneration of Sylvester Smith, see Barrett 'Falsely accused man freed' 2004 available from http:// injusticebusters.org/04/Smith_Sylvester.shtml (accessed 2016-04-20). 
also testified that Gloria indicated that Smith had told her to go in the bathroom and wash the blood off.

Both Gloria and Janell were examined at the hospital by a medical expert on 5 March, 1984. The medical expert testified that his examination of Gloria revealed 'a well-circumscribed area of bruising around the vaginal opening' on the interior of the labia. He stated that it was his opinion that a 'male penis' caused the trauma he observed. The expert also discovered the presence of protozoa trichomonas, an organism transmitted primarily through sexual contact. The expert testified that his examination of Janell revealed marked redness and irritation, with areas of contusions around the vaginal opening. He stated that a finger or penis could have caused Janell's injuries. His examinations revealed no presence of sperm, and he noted that Gloria's hymenal ring was intact.

The accused, Smith, took the stand and denied any knowledge of the incidents. Smith's denial was rejected and he was convicted and sentenced, hence the appeal to the Supreme Court of Carolina. Given that Smith's general denial of the alleged offence had no sound evidential backing, his grounds of appeal entirely revolved around the application of the rules of evidence. Amongst the grounds raised in the Memorandum of Appeal were that the trial court erred in allowing, as substantive evidence, the testimony of Mrs Davis as to what Gloria and Janell related to them following the assaults. Smith contended that this evidence was inadmissible hearsay. This ground was however rejected with the Supreme Court ruling that the hearsay evidence fell within one of the exceptions to the hearsay rule. ${ }^{16}$ The Supreme Court's decision could hardly be faulted as the law on hearsay exceptions is clear. Ultimately, the Supreme Court concurred with the trial court, consequently dismissing the appeal. ${ }^{17}$ Even without the objection to the hearsay evidence the evidence against Smith was deceptively overwhelming. The possibility of the allegations being false was hardly thought of.

\section{Sifiso Shezi Case}

In 2003, in the South African case of Sifiso Shezi, ${ }^{18}$ Shezi was sentenced to two life sentences on allegations of rape of his daughter (Dube): a sentence that many saw as justly deserved. Shezi served ten years of his

16 State of North Carolina $v$ Sylvester Smith supra $n 14$ at 839-841; for a commentary on the ruling of the Court in the case of State of North Carolina $v$ Sylvester Smith, see Holm 'State $v$ Smith: Facilitating the admissibility of hearsay statements in child sexual abuse cases' 1985-1986 North Carolina Law Review 1352-1377.

17 State of North Carolina v Sylvester Smith supra n 14 at 850.

18 Judgement unreported. Similarly, findings of the court as it pertains to the newly-discovered evidence are unreported in view of section 327(3)(b) of the Criminal Procedure Act 105 of 1977 of South Africa, which prohibits a court entertaining the new evidence from announcing its findings. However, for details about alleged false accusations, see Ayanda \& Mlambo 
jail term, during which period he maintained his innocence. Dube, who was eight years old at the time of the allegations, retracted her accusation in 2008 after her mother died and confessed that her mother had coerced her into lying about the abuse. She confessed to falsely testifying at trial because she was scared of her mother who had a bad temper. Dube also confessed to being coached by her mother to testify that her father had raped her on four different occasions. Shezi was released in 2013, having served ten years of his sentence.

It is an axiomatic truth that '[p]unishment of the innocent may be the worst of all injustices'. ${ }^{19}$ These two cases illustrate the fallout from false CSA allegations. They demonstrate, although false CSA are rare, that they are not merely rhetoric. The facts were so carefully fabricated and aligned with the circumstances: This, coupled with an attempt to protect 'innocent' child victims, led the appellate court, at the time of trial, to uphold the convictions. Smith and Sifiso maintained their innocence all along but were freed only after the victims confessed. In some cases, ' $[\mathrm{t}]$ he pendulum has swung from a reluctance to believe any charge by a child against an adult to a non-reflective embrace of every accusation made, no matter how implausible or fanciful'.20 Mantell makes the point that the potential consequences of false CSA allegations are massive, long lasting and devastating to the child, parents, family and society. Shanks similarly observes as follows: ${ }^{21}$

To be wrongly convicted of child sexual abuse has immediate and long-lasting effects on the life of the accused, including lengthy prison terms, registration as a sex offender and the conditions and consequences that follow, which may include the loss of professional licenses, inability to live within certain areas, and a lifelong stigma. Given the nature of child sexual abuse, such convictions can destroy families. The individual accused is not the only victim of wrongful convictions. A spouse who refuses to believe an accusation may lose custody of the child involved or other children in the family. She herself may be [wrongly] charged criminally for refusing to 'protect' the child from abuse. $^{22}$

Smith and Sifiso lost twenty and ten years, respectively, of their lives in prison. They are, in fact, free from 'behind bars' but may not exactly be free from stigma. Fortunately for Smith and Sifiso, the complainants confessed their earlier false accusations. Not many complainants are keen to set the record straight because of the legal consequences of false accusations. If CJSs are to accomplish much in affording protection to children, greater objectivity is called for. 'There can be no benefit to society or to children in imprisoning an innocent person merely because

'Dad cleared of rape happy to be free' 2013 available from http://www. iol.co.za/dailynews/news/dad-cleared-of-rape-happy-to-be-free- 1.1534796 (accessed 2016-04-20).

19 Jenner v Dooley, 590 N.W.2d 463, 471 (SD. 1999).

20 Shanks 2009-2010 Legal Research Paper Series supra $n 1$ at 31.

21 Mantell 'Clarifying erroneous child sexual abuse allegations' 1988 American Journal of Orthopsychiatry 618-621.

22 Shanks 2009-2010 Legal Research Paper Series supra n 1 at 23. 
the system is slanted against him'. ${ }^{23}$ The consequences of false CSA allegations are disquieting as they often result in damage to the interests of the child and to the child's primary relationships. In order to resolve the dilemma and for CJSs to become more objective, increasingly, processes must be explored that ensure that the falsely accused are vindicated and at the same time, that offenders are fully held to account. Shanks rightly notes that it 'is imperative that improvements be made to ensure that individuals are not convicted of crimes they did not commit and that children are not the unwitting accomplices in such miscarriages of justice'. ${ }^{24}$ Sutherland J, in the case of Evans Michael $v$ The State, has equally demonstrated the need for courts to be cautious when confronted with CSA cases, stating that it is defensible for CJSs to be zealous about holding child sexual offenders to account: ${ }^{25}$

[t]here is however a real danger that our indignation at the violation of the right to dignity of the vulnerable people can cripple our critical faculties. When that happens, there is a danger that one reaches for what is thought to be the right outcome without having properly conducted the fact finding exercise upon which to create a platform to stand and assert one's values.

The current state of affairs definitely warrants intervention. If accurate and correct decisions are to be arrived at during all stages of the process of criminal prosecution, then perhaps CJSs should consider increasingly engaging with MHPs and making the process of cross-examination more meaningful and inquisitorial. The next section engages with the latter two mechanisms and how they can be used to confront the rare, but pervasive, cases of false CSA allegations.

\section{The Need for MHPs to Substantiate on CSA Reports and Assess the Competence of CSA Victims to Testify}

Studies demonstrate that attempts to vindicate the falsely accused in CSA cases are fraught with difficulties. ${ }^{26}$ CJSs are presented with a dilemma of balancing the obligation to protect CSA victims and at the same time guaranteeing the rights of those suspected of abuse. This dilemma is

23 Elder 'Investigation and prosecution of child sexual abuse cases' 1991 Western State University Law Review 285; see also Rogers 'Coping with alleged false sexual molestation: Examination and statement analysis procedures' 1990 Issues in Child Abuse Accusation 57-68.

24 Shanks 2009-2010 Legal Research Paper Series supra n 1 at 29

25 Evans Michael $v$ The State case no 2011/A46 unreported par 4.

26 Yuille et al supra n 5 at 24; Raskin \& Yuille 'Problems in evaluating interviews of children in sexual abuse cases' in Cece et al (eds) Children take the stand: Adult perceptions of children's testimony (1989) 184-207; see also Ash \& Guyer 'Child Psychiatry and the law: The functions of psychiatric evaluation in contested child custody and visitation cases' 1986 Journal of American Academy of Child Psychiatry 554-561; Benedeck \& Schetky 'Allegations of sexual abuse in child custody and visitation disputes' in Benedeck \& Schetky (eds) supra $n 7$ at 145-156; Corwin et al 'Child sexual 
complicated by the fact that these cases hardly have conclusive medical evidence or eye witnesses to aid in substantiation. Many cases are not straight-forward, making it difficult to arrive at a clear-cut decision as to whether or not CSA occurred. Empirical research cites a host of symptoms as indicia of CSA in children; some symptoms may be evident in non-abused children, let alone symptoms caused by stressors other than sexual abuse. Equally important is Browne and Finkelhor's demonstration that not all sexually abused children necessarily show behavioural symptoms in reaction to CSA. ${ }^{27}$ Therefore, there is no doubt that the task of deciding whether a child was abused in these circumstances is difficult. Yuille et al note, in circumstances such as these, that 'the job of assessment requires more than knowledge that such symptoms do or do not exist'. ${ }^{28}$

Myers et al caution judicial officers on the need to avoid underestimating the complexity and the degree of expertise required for evaluation of suspected CSA. ${ }^{29}$ The authors explain that the evaluator must possess specialised knowledge of child development, individual and family dynamics, patterns of child sexual victimisation, signs and symptoms of abuse, and the uses and limits of various psychological tests. The competent evaluator must equally be familiar with the literature on child abuse and understand the linkage between behavioural reactions and CSA. Short of this knowledge, courts run the risk of arriving at uninformed decisions. Uninformed decisions either predispose the children to further CSA due to a failure to hold offenders to account, or account for the wrongful conviction of the falsely accused. The broad prerequisites described by Myers et al make the opinion of MHPs relevant in aiding CJSs in substantiating CSA allegations. Certainly, MHPs cannot distinguish between false and genuine CSA allegations, but they can provide the court with knowledge otherwise, not available to the court, which can improve a courts' assessment of CSA allegations. These experts do not have absolute criteria to discriminate false allegations from genuine allegations, nonetheless they have a better appreciation of the implication of behavioural and psychological reactions among children. Yuile et $a l^{30}$ demonstrate that MHPs, properly qualified, can apply a number of techniques to improve assessment of CSA allegations. The authors mention three techniques that can be used by MHPs to substantiate CSA allegations: these are behavioural checklists, recantations and credibility assessments. ${ }^{31}$

abuse and custody disputes: No easy answers' 1987 Journal of Interpersonal Violence 91-105; de Young 'A conceptual model for judging the truthfulness of a young child's allegations of sexual abuse' 1986 American Journal of Orthopsychiatry 550-559.

27 Browne \& Finkelhor 'Impact of child sexual abuse: A review of the research' 1986 Psychological Bulletin 66-77.

28 Yuille et al supra $n 5$ at 24.

29 Myers et al 'Expert testimony in child sexual abuse litigation' 1989 Nebraska Law Review 42.

30 Yuille et al supra $\mathrm{n} 5$ at 24.

31 Ibid. 
Further, the appointment of MHPs as experts is particularly appropriate in a case in which there is no physical evidence or any corroboration of the allegation, for instance, if the testimony of a young child is the only evidence of a serious criminal accusation, as is often the case in CSA cases. An expert witness can be appointed to aid the court in assessing the competency of children to testify if the court feels that the child's developmental maturity is in question. A child psychologist can evaluate the child using developmentally appropriate techniques to ascertain the child's level of developmental maturity and her ability to accurately relate a series of events. In this regard, the expert can aid the court in accurately appraising the child's ability to testify as opposed to allowing an incompetent child to take the stand or preventing a competent one from doing so.

Presently, the techniques of assessing the competence of children are out of touch: traditionally, according to Spencer, the nature of an oath for purposes of assessing the competence of a witness to testify meant "saying that you believed you would burn in hell forever if you lied'. 32 Techniques applied to determine the competency of children to testify make 'little or no attempt to accurately ascertain the child's level of developmental maturity or ability to reliably relate a series of events'. 33 Indeed, the competency rules have been the subject of criticism and, consequently, have attracted reform in some justice systems with the competency requirement being abolished in some systems. ${ }^{34}$ Increasingly it is acknowledged that all children who are capable of communicating intelligibly are competent to give evidence. Although this is a welcome innovation, in some cases there has been a shift from a reluctance to consider children competent to a non-reflective consideration of children as competent or incompetent.

Children who are capable of communicating intelligibly should be considered competent to give evidence, however, the process of assessing the competency of these children should advance more accurate findings on competency. CSA allegations are too serious for issues pertaining to the competency of children to testify, to be left to speculation and procedures whose accuracy is wanting. As Shanks notes: ' $[t]$ he lives of many individuals, including the child, will be changed forever as a result of the determination made at the competency

32 Spencer 'Introduction' in Spencer \& Lamb (eds) Children and cross examination: Time to change the rules? (2012) 6.

33 Shanks 'Evaluating children's competency to testify: Developing a rational method to assess a young child's capacity to offer reliable testimony in cases alleging child sex abuse' 2010 Cleveland State Law Review 575. See also SvN 1996 (2) SACR 225 (C); S v Seymour 1998 (1) SACR 66 (NPD); and Sv Malinga 2002 (1) SACR 615 (NPD), on the import and nature of an oath and its implications on evidence of children.

34 See e.g. s 52 of the Criminal Justice Act of England 1988, which abolished the competence requirement; see also South Africa's SCA's decision in $S v B$ 2003 (1) SACR 52 (SCA), where Streicher JA observed that an understanding on the complainant's part of the nature and import of the oath did make the evidence she gave less reliable. 
hearing, ${ }^{35}$ However, in carrying out this assessment, often the process 'is both startling and [it is] problematic that the typical competency hearing is comprised of ... meaningless ceremony'. ${ }^{36}$ For example, the process in the 2012 CSA decision of $S v$ Matshivha (Matshivha case), in which the competence of the complainant was assessed, comprised of the following questions:

Do you know your age - Yes?

How many? - I am eight years old.

Do you know the difference between the truth and a lie - Yes

When a person lies is when a person is telling what? The truth or is when the person is not telling the truth. When it said that, that person is telling a lie That is one person would be telling lies [sic].

You speak lies? - No

What do you speak? - The truth

Thank you, you may proceed. ${ }^{37}$

Shanks persuasively observes that, ideally, the 'salient questions' in assessing the competence of children to testify should be 'whether the child can observe and register what happened, whether she has memory sufficient to retain an independent recollection of the events, whether she has the ability to translate into words the memory of those observations, and whether she has the ability to understand and respond to simple questions about the occurrence'. 38 'Unfortunately, [in most cases] these critical skills are rarely explored during the competency hearings ... Rarely are competency hearings used to assess the types of issues that are critical in criminal cases, such as the child's understanding of the concepts of time and ability to accurately perceive and relate a series of events. 39 The questions in the Matshivha case above are the typical competence questions asked: often, questions pertain to a child witness' residence, name, age, ability to differentiate colours, among other general aspects. The answers and assessment with regard to this line of questioning are certainly within the common knowledge of judicial officers, hence, the justifiable option for judicial officers to dispense with MHPs in assessing the child witness' mental capacity and competency.

However, it is submitted that if false CSA allegations are to be increasingly confronted, an assessment of children's competence to testify will need to go further than generalised questioning. The aspects underscored by authors like Shanks above will need to be considered in informing the line of questioning and assessment. Judicial officers should

35 Shanks 2010 Cleveland State Law Review supra n 33 at 576.

36 Idem 578.

37 S v Matshivha (2014) 1 SACR 29 SCA par 7 . As can be gleaned from the quote above, the questions are not only confusing and hard to follow, they also fail to address issues relevant to assessing children's competence.

38 Shanks 2010 Cleveland State Law Review supra n 33 at 585.

39 Ibid. 
ensure, by the time the child complainant is deemed competent to testify, that the judicial officer has made an attempt to accurately ascertain the child's level of developmental maturity or his or her ability to reliably relate a series of events. This attempt will ensure that the accused are not convicted based on evidence of an ideally incompetent child complainant. Similarly, a broader view of assessment will ensure that child complainants, who are capable of testifying credibly, are not precluded from testifying based on generalised questions that fail to touch upon salient issues relevant in assessing competence. If such detailed assessment is to be explored, the expertise of MHPs will, seemingly, be indispensable as this wider scope touches upon the child's ability to differentiate between fantasy and reality in a particular case, the child's understanding of the concept of truth, his or her memory, children's enactive representation, imaginal representation, linguistic representation, categorical representation, capacity to observe, ability to communicate, among other more specialised aspects. Judicial officers can benefit from the expertise of MHPs: a more accurate assessment definitely, will be arrived at if judicial officers receive appreciable help from MHPs. In furtherance of greater objectivity in CSA prosecutions, courts should increasingly accommodate help from MHPs. The costs associated, admittedly, may be significant, but these costs pale in comparison to the injustice of punishment of the innocent on account of a failure to explore mechanisms that enhance accuracy.

\section{The Need for Meaningful Cross-examination in Testing the Evidence of Alleged CSA Victims}

An essential component of an adversarial trial is cross-examination. According to Davies, cross-examination is the strategy of words and actions which the advocate employs during presentation of evidence by the opposition that serves to cast doubt upon the opposing party. ${ }^{40}$ Generally, the ideal purpose of cross-examination, as a technique in adversarial systems of justice, is to test the accuracy of evidence adduced by the opposing party. According to Zeffert and Paizes, 'the purposes of cross-examination are, first, to elicit evidence which supports the crossexaminer's case, and second, to cast doubt upon the evidence given for the opposing party'. ${ }^{41}$ Ellison adds that '[i]nordinate faith is placed in the capacity of the skilful cross-examiner to expose the dishonest, mistaken or unreliable witness, and to uncover inconsistency and inaccuracy in oral testimony'. 42

The two cases discussed in the preceding section demonstrate that the potential of an innocent person being convicted and sentenced to lengthy imprisonment is present. In these cases, wrongful identification

40 Davies Anatomy of cross examination (1993) 3.

41 Zeffertt \& Paizes The South African Law of Evidence (2009) 909.

42 Ellison 'The protection of vulnerable witnesses in court: An Anglo-Dutch comparison’ 1999 International Journal of Evidence \& Proof 35. 
arose where very young CSA victims failed to appropriately identify the actual offender or the children were coerced into making a false accusation. Substantiation of CSA allegations is extremely difficult. As Mlambo $J$ put it in $S v N d l o v u,{ }^{43}$ in these circumstances, "[C]rossexamination [becomes] an integral part of the armoury placed at the disposal of an accused person to test, challenge and discredit evidence tendered against him or her'. Khumalo AJ, in the 2012 judgement in Muntuza $v$ The State, adds that ' $[\mathrm{t}]$ he rule serves as a protective measure against the danger of an accused being found guilty on the strength of the evidence of a witness who is unreliable or lacks credibility'. ${ }^{4}$

Cross-examination, if appropriately conducted, can play a critical role in testing the evidence of child witnesses. However, legal practitioners often fail to make the best out of this process to advance this purpose. Presently, cross-examination of child witnesses is generally depicted in a bad light: it has been reduced to a technique of coercion, intimidation and the use of complex language to confuse child witnesses as opposed to being a procedure for testing evidence. ${ }^{45}$ Cossins observes that 'rather than being a method for uncovering the untruthful child witness, empirical evidence shows that it is a process that manufactures inaccurate evidence'. ${ }^{46}$ Often, the mode of questioning is characterised by closed-ended and leading questions which fail to further truthfinding. ${ }^{47}$ Ellison observes that, in some cases, the process of crossexamination is gruelling, comprising of undue vigorous objections, warnings, reminders, repetition of questions and the insistence on proper answers. ${ }^{48}$ These techniques fail to take into account the plight of vulnerable witnesses. For children, these techniques have been found to be abrupt, frustrating and degrading to the child witness and they dramatically reduce the scope for clarification, explanation and elucidation. ${ }^{49}$ The process is compounded by undue focus on peripheral issues, often incidental to the ultimate issue for determination. ${ }^{50}$ Research demonstrates that children, generally, may not be able to give an account of the details surrounding incidents, let alone those that are peripheral. ${ }^{51}$ What Wigmore termed the 'greatest engine ever invented

43 S v Ndlovu 2002 (2) SACR 325 SCA.

44 Muntuza $v$ The State case no A868/2011 (unreported) par 18.

45 Ellison 'The mosaic art?: Cross-examination and the vulnerable witness' 2001 Legal Studies 354-360.

46 Cossins 'Cross-examining the child complainant: Rights, innovations and unfounded fears in Australian context' in Spencer \& Lamb (eds) supra n 32 at 111 .

47 Ibid.

48 Ellison 2001 Legal Studies supra n 45 at 359.

49 Ibid.

50 Ibid

51 Goodman \& Helgeson 'Child sexual assault: Children's memory and the law' 1985 University of Miami Law Review 186; Christiansen 'The testimony of child witnesses: Fact, fantasy, and the influence of pretrial interviews' 1987 Wash. L. Rev. 705-721; Yuille 'The systematic assessment of children's testimony' 1988 Canadian Psychology 247-262; Muller Prosecuting the child offender (2011) 165. All these authors affirm that it is possible for detailed 
for the discovery of truth' has, in some cases, turned out to be the greatest engine for distorting the accuracy by evidence of child witnesses. ${ }^{52}$ Muller rightly observes that 'it would appear ... that crossexamination has much to do with a battle between the two parties and very little to do with the need to establish the truth'. ${ }^{53}$

Since false CSA allegations are a reality, it is critical that crossexamination is not merely a tool for confusing child witnesses but for putting the evidence of children to the test in order to ensure that the falsely accused are not convicted. Some techniques used fail to advance the essence of cross-examination and, instead, traumatise child witnesses. Kassin et al have called these techniques 'dirty tricks' that mask the ideal essence of cross-examination making it hard for courts to make sound credibility judgements. ${ }^{54}$ In Carroll v Caroll, Henochsberg AJ underscored the ideal essence of cross-examination by stating as follows:

The objects sought to be achieved by cross-examination are to impeach the accuracy, credibility and general value of the evidence given in chief, to sift the facts already stated by the witness, to detect and expose discrepancies or to elicit suppressed facts which will support the case of the cross-examining party. ${ }^{55}$

Ideal techniques of cross-examination should test the evidence of child victims so that, at the end of the process, the reliability or non-reliability of their evidence is brought to the attention of the court. In the cases of child witnesses, it is particularly important that their evidence is not subjected to archaic cautionary rules, but that sympathy, on account of their tender age, does not obscure the need for common sense and objectivity in testing their evidence. This requirement is pivotal since it is possible for children to attract sympathy from the system: Spencer, for instance, paints a vivid picture of the dilemma of dealing with very young children as witnesses by observing as follows:

Meaningful communication often proves impossible, particularly with little children. Sometimes they cannot be persuaded to say anything intelligible, even though they managed to communicate intelligibly during the videointerview that has now taken the place of their evidence in chief. Sometimes they are able to communicate intelligibly, but cannot be cross-examined to any useful purpose because by the time of trial they have forgotten all about the incident. And sometimes they cannot be cross-examined because they are scared out of their wits and unable to communicate at all: like a little girl

and accurate testimony to be elicited from a child victim. The authors, however, observe that generally, children often recall less than adults do. When appropriately questioned, the authors contend that children are more likely to answer correctly questions about central actions than questions about peripheral information.

52 Wigmore $A$ treatise on the Anglo-American system of evidence in trials at common law (1940) 1367.

53 Muller supra $\mathrm{n} 51$ at 146.

54 Kassin et al 'Dirty tricks of cross examination: The effect of conjectural evidence on juries' 1990 Law \& Human Behaviour 374.

55 Carroll v Caroll 1947 (4) SA 37 (W) 40. 
in a case ... who got up from her chair as soon as the cross-examination started and just ran away. ${ }^{56}$

Notwithstanding these vulnerabilities, it would be unrealistic to dispense with cross-examination techniques geared towards testing the credibility of the child victim. The '[f]ailure to allow cross-examination constitutes a gross irregularity'. 57 The court has no right to prevent crossexamination even if the purpose is to protect the witness. In $S v$ Manqaba, ${ }^{58}$ a magistrate prevented cross-examination of a child witness. The main reason for the refusal was the possible traumatisation of the child. Satchwell $\mathrm{J}$ found that this refusal was an irregularity which negated the right of the accused to a fair trial because the refusal to allow cross-examination "was predicated upon an expresses intention by the magistrate to protect the complainant at the expense of the accused'.

In some CSA cases it is hard to substantiate the CSA allegations, thus it should be permissible for the credibility of the CSA victim to be attacked. What is critical during this process, is for the examiner to ensure, in testing the credibility of the child witness, that the process is not used as a platform to further myths about CSA. Equally, the crossexaminer should ensure, as much as is possible, that the examination technique is adapted to the developmental abilities and vulnerabilities of children 'to enable the child to give the best evidence of which [the child] is capable' while, at the same time, ensuring the accused person's right to a fair trial. ${ }^{59}$ Zeffert and Paizes note 'a witness' credit [for purposes of cross-examination] means not only his honesty but also his powers of perception, memory and accuracy of narration'. ${ }^{60}$ Therefore, it is unrealistic to assume that the evidence of child witnesses will be tested without any emphasis on their credibility whatsoever. It is to be noted, even with appropriate techniques, that examining the child witness to establish their honesty, power of perception, memory and accuracy may not necessarily be appealing to the child witness: realistically, some degree of discomfort on the part of the child is to be expected where their credibility is being tested.

Legal practitioners should increasingly test the credibility of CSA victims, in an inquisitorial manner, so as to expose the child's reliability or unreliability with a view to arriving at the truth. In essence, aspects of the CSA victim's evidence which reveal dishonesty, incompetency, poor powers of perception of the alleged CSA incident and inaccuracy in narration, should be brought to the attention of the court so that the innocent are not wrongly convicted. Cross-examination should enhance the credibility of CSA victims who are competent, accurate and honest and at the same time diminish the credibility of those who are

56 Spencer 'Introduction' in Spencer \& Lamb (eds) supra n 32 at 11.

57 Schwikkard Principles of evidence (2010) 366.

$58 S v$ Manqaba 20052 SACR 489 (W) parr $55 \& 58$.

59 Plotinkoff \& Woolfson 'Kicking and screaming: The slow road to be evidence in Spencer \& Lamb (eds) supra $n 32$ at 30.

60 Zeffertt $\&$ Paizes supra $n 41$ at 910. 
incompetent, dishonest and inaccurate. Only appropriate techniques of cross-examination further this cause. Legal practitioners should be equipped with more appropriate techniques to reveal evidence that undermine the CSA victim's credibility. This notion was affirmed by the England and Wales Court of Appeal in the 2010 CSA judgement of $R v$ Barker. The court ruled:

[w] hen the issue is whether the child is lying or mistaken in claiming that the defendant behaved indecently towards him or her, it should not be overproblematic for the advocate to formulate short, simple questions which put the essential elements of the defendant's case to the witness, and fully to ventilate before the jury the areas of evidence which bear on the child's credibility. Aspects of evidence which undermine or are believed to undermine the child's credibility must, of course, be revealed. ${ }^{61}$

Taken together, cross-examination, as a technique of testing the evidence of children, is increasingly losing its efficacy because of the poor techniques applied by lawyers. Therefore, it is unsurprising that this procedural right is increasingly being questioned. However, if cases of false CSA allegations are to be appropriately dealt with, this procedure seems indispensable. Cross-examination is more likely to help in substantiating CSA allegations if legal practitioners adapt their examining techniques to the developmental abilities and vulnerabilities of children - such techniques will more readily expose the truth as opposed to confusing and misleading children. For example, the cross-examination of the CSA complainant in the case of $S v$ Nozazaku comprised of the following questions:

I'm going to put it to you that you are fabricating this now, Tuliswa. That the impression that you gave to this court the whole time was that that vehicle was locked and that you never unlocked or attempted to unlock that vehicle.

Now, if your aunt said to the court yesterday that it is a busy shebeen and that while she was there she saw people coming in and leaving the shebeen and she described that she can't say how many but she gave the indication that they were a lot of people. What would you say to that?

Now, I'm going to put it to you that if necessary there will be people that will say when you told the police inside the charge office at Motherwell, giving a description when or where and how you were raped, you told the police you were raped at the Smirnoff board at Zwide.

Can you tell His Worship what the blanket is used for?

I'm going to put it to you that you are fabricating now, Tuliswa.

You see why I'm asking you the question, Tuliswa, is, my learned friend, when she led you in evidence in chief, she put two questions to you. ${ }^{62}$

It is unlikely techniques such as these meaningfully elicit truth from the child complainant. Therefore, it is submitted, for children, that crossexamination techniques should be more inquisitorial - questioning

$61 \quad R v$ Barker (2010) EWCA Crim 4 par 42.

$62 S v$ Nozakuzaku 1995 case no RC 6/68/95(E) (unreported). Extracts obtained from Muller supra n 51 at 161-162. 
techniques that inquire into unclear issues, seeking explanation for a lack of clarity, amount to a more meaningful method of cross-examination with a view to furthering the truth. Only if cross-examination is conducted meaningfully, will it serve the purpose of vindicating the innocent, namely, the innocent children who are used as conduits of false or mistaken CSA allegations, and the falsely accused. If done poorly, cross-examination can unduly erode or limit the testimony of CSA victims. However, if appropriately conducted, it can succeed in substantiating on unclear issues. As Shanks observes '[i]t is hard to overemphasise the importance of confrontation and effective crossexamination to the defense of an individual accused of a crime'. ${ }^{63}$

\section{The Need for an Appropriate Forum to Entertain Newly-discovered Evidence}

Not many complainants are keen to set the record straight in cases of false CSA allegations - very few cases of this nature come to the attention of the public and CJSs. However, in the exceptional circumstance of a case being brought to the attention of CJSs, there is often newlydiscovered evidence which has the potential to establish the innocence of the convict who is serving a sentence. The newly-discovered evidence often fundamentally affects the earlier conviction and sentence. Currently, in most CJSs, the only legal procedure available to convicted persons who have exhausted legal procedures by way of appeal and review is a pardon or executive clemency. This is based on the popular assumption that the 'traditional fail safe remedy for claims of innocence based on new evidence discovered too late' is executive clemency. ${ }^{64}$ Executive clemency is a concept of mercy and pardon that is constitutionally recognised in most countries. ${ }^{65}$ It serves to show compassion by relieving an individual of the full weight of their sentence and to correct errors in the judicial process - the offender, therefore is unconditionally forgiven. 66

In some cases executive clemency may involve courts - particularly if new evidence has been discovered which significantly impacts on the earlier conviction. For example, in South Africa's CJS, section 327 of the Criminal Procedure Act 105 of 1977 (CPA), provides for free pardon or substitution of a verdict by the president where new evidence has since been discovered after the trial. Executive clemency, with the involvement of the courts, arises if the convict has exhausted all the

\footnotetext{
63 Shanks 2010 Cleveland State Law Review supra n 33 at 594.

64 Herrera $v$ Collins 506 US 390 (1993) 417.

65 See e.g. s 84(2) (j) of the Constitution of the Republic of South Africa of 1996; art 121 of the Constitution of the Republic of Uganda of 1995.

66 Smith 'The prerogative of mercy, the power of pardon and criminal justice' (1983) Public Law Journal 398.
} 
recognised legal procedures in the form of appeal and review. ${ }^{67}$ The convict or their legal representative addresses the minister of justice by way of petition indicating that further evidence has since been discovered which materially affects his or her conviction. ${ }^{68}$ The minister may direct that the petition be referred to the court in which the conviction occurred. ${ }^{69}$ The court may examine any witnesses in connection therewith. ${ }^{70}$ The court assesses the value of the further evidence and advises the president on the extent to which the evidence affects the conviction in question. ${ }^{71}$ The court, however, cannot announce its findings as to the further evidence or the effect thereof on the conviction in question. ${ }^{72}$ The president, upon consideration of the advice of the court, may direct that the conviction in question be expunged or substitute the conviction in question with a conviction of lesser gravity. ${ }^{73}$ The president, however, is not bound by the findings of the court on the newly-discovered evidence and its implication for the conviction in question.

In the cases discussed above, it is indisputable that the newlydiscovered evidence significantly impacted on the earlier conviction. ${ }^{74}$ Since, for many CJSs, executive clemency is the only post-conviction procedure available to convicts in cases of newly-discovered evidence, this seems to be the only procedure at the disposal of the falsely accused in CSA cases. It suffices to note, with regard to executive clemency, that in the eyes of the law, the petitioner does not come before the court as innocent but as a person in need of mercy, compassion and forgiveness. ${ }^{75}$ With the procedure in section 327 of the CPA, the newlydiscovered evidence, although highly probative in establishing the petitioner's innocence, merely serves as a pathway to executive clemency, without which the petitioner would not have had the opportunity to benefit from clemency. It suffices to note further that despite the high probative value of the newly-discovered evidence, in the form of a confession or recantation, the discretionary nature of executive clemency means that clemency cannot be guaranteed. The findings of the court with regard to the newly-discovered evidence and its implication for the conviction cannot guarantee clemency because these findings are not binding on the president.

\footnotetext{
67 S 327(1) of the Criminal Procedure Act 105 of 1977.

68 Ibid

69 Ibid.

70 Idem s 327(2)

71 Idem s 327(4)(a).

72 Ibid.

73 Idem s 137(6).

74 In both cases, the complainants at the time of trial confessed to falsification of the CSA allegations.

75 See e.g. Herrera $v$ Collins supra $n 64$ at 390, where the United States Supreme Court noted that '[i]n criminal cases, the trial is the paramount event for determining the defendant's guilt or innocence'. After trial, the presumption of innocence does not suffice but rather, compassion, mercy and forgiveness.
} 
It is submitted that confessions on falsification of CSA allegations excluding the convict from the list of suspects, are forms of evidence that are too highly probative to be subjected to the discretionary nature of executive clemency. The high probative value of this evidence is apparent in the two discussed cases of Smith and Sifiso. Discretionary executive power does not seem to be the best forum to address such strong claims pointing to the petitioner's innocence. Petitioners must be given an opportunity to directly apply to the court that found them guilty to have newly-discovered evidence tested. ${ }^{76}$ The state, equally, should be notified of the application and given an opportunity to respond. The court must admit the evidence and consider it in conjunction with the trial transcript and any other relevant evidence. Depending on the court's objective analysis, the court should be able to uphold the conviction or set it aside. Leaving referral of the petition to court to the discretion of the minister is problematic as the minister can chose not to have the petition referred to a court. Arming courts with the power to directly receive the petitions and to arrive at binding decisions with regard to the newly-discovered evidence affords broader protection to both the petitioner and the 'earlier complainant'. Subjecting the newly-discovered evidence to test by the courts, coupled with the power of courts to arrive at objective, binding decisions with respect to the new evidence guarantees that the objective findings of court trickle down to the final decision. Again, in arriving at this decision and testing the confession, the role of MHPs remains pivotal in availing courts of knowledge about the genuineness and the circumstances surrounding the recantation. Therefore, it is submitted that executive clemency, akin to that under section 327 of South Africa's CPA, does not seem to be an appropriate forum in cases involving evidence that is highly probative of the petitioner's innocence: because, even with the high probative nature of the newly-discovered evidence, there is no guarantee that the falselyaccused, in CSA cases, are protected. It suffices to note that with such strong claims, the petitioner is not necessarily seeking compassion or forgiveness but asserting that it was wrong for him or her to be convicted in the first place - in light of the newly-discovered evidence. Removing such strong claims from the arena of executive discretion, it is argued, is a furtherance of the greater goal of objectivity in dealing with CSA cases.

Certainly, with this proposal the principle of finality is defied. ${ }^{77}$ However, to the extent that life and liberty are at stake, a different

76 This is the position in cases of newly-discovered deoxyribonucleic acid testing (DNA) evidence in Criminal justice systems such as America's. Because of the high probative value of the evidence, such as DNA, the current trend in the courts in America is that the petitioner should be given an opportunity to show their innocence. Confessions of falsification may not necessarily constitute scientific evidence: they also constitute strong claims of innocence to warrant removal from the arena of executive discretion.

77 The principle of finality is based on the reasoning that both the accused and society have an interest in ensuring that there, at some point, will be the certainty that comes with an end to litigation, and that attention will 
procedure should govern evidence of a high probative nature in CSA cases than in cases in which evidence is not so probative. It is submitted that cases such as Smith and Sifiso present powerful claims of innocence and is coupled with evidence which is highly probative in establishing the petitioner's innocence. Petitioners, in cases such as these, must be given an opportunity to prove their innocence. It is argued that taking false CSA allegations seriously requires courts to be open to powerful claims of innocence without regard to whether procedural guidelines, challenging a conviction, have been exhausted or have expired - it should never be too late for innocence to be established. Sufficient showing of probable innocence should trigger a due process right to a judicial hearing on newly-discovered evidence. The standard applicable in this regard should be 'whether after viewing the evidence in the light most favourable to the prosecution, any rational [judge] could have found the essential elements of the [child sexual offence] beyond a reasonable doubt'. ${ }^{78}$ Admittedly, reforms such as these might be the subject of considerable opposition, however, it is hoped, over a period of time, this trend could be reversed.

\section{Conclusion and Recommendations}

Even the most vehement critics of the CJS concede that the conviction of those who are innocent is rare. ${ }^{79}$ Wrongful conviction in CSA cases, although extremely minimal and occasional, can undermine public respect for and confidence in the legal system and law enforcement. These risks suggest a greater call for objectivity and a need to take claims of wrongful conviction more seriously. Human error is inevitable and no CJS can purport to be perfect. However, it is critical, as much as possible, that CJSs make the best of available mechanisms to improve their accuracy. In CSA cases in which there is often hardly any medical evidence, the role of MHPs is critical in evaluating CSA allegations and assessing the competence of children to testify. Furthermore, over the years, the ideal essence of cross-examination has been undermined. Often defence attorneys fail to make the process meaningful in furtherance of the truth. Therefore, it is critical for legal practitioners to get back to the 'real' essence of cross-examination. A more inquisitorial approach in furthering this process seems inevitable. Equally, if new evidence with the effect of proving innocence has been discovered long after conviction and sentence, it is particularly important that the doors to proving innocence are not closed. Where new evidence has since been discovered, that backs stronger claims of innocence, it is recommended that those falsely-accused of CSA be afforded a judicial platform to prove their innocence.

ultimately be focused not on whether a conviction was free from error but rather on whether the prisoner can be restored to a useful place in the community.

78 Jackson v Virginia 443 U.S. 307, 319 (1979).

79 See e.g. Green "Lethal fiction: the meaning of "counsel" in the Sixth Amendment' 1993 Iowa Law Review 504. 
If they are to take the incidence of false CSA allegations and wrongful conviction more seriously, legal professionals are faced with obligations. Defence attorneys need to reconsider their technique of crossexamination in testing the evidence of children - the process should, preferably, be inquisitorial with the aim of unravelling the truth as opposed to it being used as a weapon to confuse and traumatise children. Judges are vested with the power to arrive at decisions about the competence of children to testify, and it is therefore critical for competence assessments not to be reduced to mechanical processes. Judicial officers should see to it that the competence assessment is meaningful to ensure that convictions are not based on the evidence of incompetent child witnesses. Defence attorneys should play a more active role in the competence assessment process and, where need be, make use of MHPs to challenge the competence of child witnesses to testify, particularly if their competence is in question. Prosecutors bear the obligation to call witnesses. In this regard MHPs should be increasingly incorporated in their witness lists in CSA cases. The task of prosecutors should not merely be to secure convictions - as officers of the court and administrators of justice, prosecutors should ensure that 'justice' is done. 